Jourat homepage: www.aesacademy.org

ORIGINAL RESEARCH ARTICLE

\title{
Physiological parameters and yield differ in rice (Oryza sativa L.) cultivars with variable water management systems
}

\author{
U.K. Sarker, M.R. Uddin ", M.A.R. Sarkar, M.A. Salam and A.K. Hasan \\ Department of Agronomy, Bangladesh Agricultural University, Mymensingh-2202, BANGLADESH \\ *Corresponding author's E-mail: romijagron@bau.edu.bd
}

\section{ARTICLE HISTORY}

Received: 08 October 2017

Revised received: 07 November 2017

Accepted: 14 November 2017

Keywords

Growth stage

HYV rice

Water stress

Subtropical environment

Water productivity

\begin{abstract}
Yield reduction of rice is a severe problem due to the advent of increasing water scarcity and efficiency is relatively low. Physiological attributes and yield performance of high yielding (HYV) rice cultivars need to be assessed by minimizing water loss. Therefore, a glasshouse experiment was conducted in Bangladesh to investigate the impact of cultivars and water management on growth dynamics, biomass production, and yield and water productivity. Ten HYV boro (dry season irrigated) rice cultivars along with fivewater management systems were included in the study. The study revealed that cultivars Binadhan-10 had higher value of leaf area index (LAI), root dry weight along with moderate panicle length. Accordingly, the cultivar Binadhan-10 had a higher yield than all other cultivars because of the highest total dry matter (TDM), number of effective tillers hill ${ }^{-1}$, and number of grains panicle ${ }^{-1}$. Growth, TDM, and yield were increased with water application up to 8 DAD after which these factors declined with increasing water stress at 10 DAD. The crop grown at CS condition did not increase the yield, rather caused the wastage of irrigation water. The water productivity was the highest $\left(0.252 \mathrm{t} \mathrm{ha}^{-1} \mathrm{~cm}^{-1}\right)$ in $10 \mathrm{DAD}$ treatments, obviously due to minimum water use but highest yield was observed in $8 \mathrm{DAD}$ because of optimum use of water and non stress condition. Therefore, the present study was useful in the screening of the most efficient cultivars, which could be strongly recommended to rice growers to improve crop yield and reduce the use of water.
\end{abstract}

(C)2017 Agriculture and Environmental Science Academy

Citation of this article: Sarker, U.K., Uddin, M.R., Sarkar, M.A.R., Salam, M.A. and Hasan, A.K. (2017). Physiological parameters and yield differ in rice (Oryza sativa L.) cultivars with variable water management systems. Archives of Agriculture and Environmental Science, 2(4): 247-256, DOI: $10.26832 / 24566632.2017 .020401$

\section{INTRODUCTION}

In recent years, agriculture is facing two major challenges that include enhancement of food production sustainably to feed a growing world population and this increment needs to be accomplished under conditions of increasing scarcity of water resources (Bouman, 2007). Rice (Oryza sativa L.) is the principal staple food for more than $50 \%$ of the world's population (Jahan et al., 2017). The world's farmers have to produce about $60 \%$ more rice than at present to meet up the food demands of the expected world population by 2025 (Fageria, 2007). Rice production under irrigated condition is the leading consumer of water in the agricultural sector, and its sustainability is intimidated by increasing water scarcity. In consequence, rice production in Asia is increasingly constrained by water limitation (Arora, 2006) and increasing pressure to reduce water use in irrigated production as a consequence of global water crisis (Tuong and Bouman, 2002). Irrigated lowland rice consumes more than $50 \%$ of total freshwater, and irrigated flooded rice requires two or three times more water than other cereal crops, such as wheat and maize (Barker et al., 1998; Sarkar et al., 2017). For $1 \mathrm{~kg}$ of rice, it is estimated that farmers use 3 to 4 thousand litres of water whereas it actually needs 1.0 to 1.5 thousand litres only. Thus, for irrigation farmers have to pay about $30-40 \%$ of the extra cost. This might be due to their ignorance about the need of water for rice cultivation as well as consequence of misuse of water. In addition, rice production is facing increasing competition with rapid urban and industrial development in terms of freshwater resource (Bouman and Tuong, 2001). The need for "more rice with less water" is crucial for food security, and irrigation plays a greater role in meeting future food needs than it has in the past (Tuong et al., 2005). This issue will necessitate the development of substitute irrigated rice production systems that involve less water than conventional flooded rice (Bouman et al., 2005).

Different water saving techniques for rice production have been evolved by researchers such as alternate wetting and drying (AWD) (Bouman and Tuong, 2001; Belder et al., 2004), saturated soil culture (Tuong et al., 2005), direct dry seeding (Tabbal et al., 2002; Rahman, 2016), and aerobic rice culture (Bouman et al., 2005; Kato et al., 2009). These have been found to be effective in reducing water use and improving water productivity, but there are debates on whether these water-saving techniques will increase or decrease rice yields (Bouman et al., 2007). The lower productivity of rice is associated with drought stress arises from these technologies. This stress has now become a severe threat to ensure food 
security in the developing world as well as in Bangladesh. Although water is required all over the growth periods of rice plant, there are some critical growth stages when drought stress impacts seriously and create a massive reduction in quantity and quality of yield.

Plants respond to drought stress at the molecular, cellular and physiological levels which vary among species and genotype, length and severity of water stress, crop age and stage of development, organ and cell type and sub-cellular compartment (Yamakawa et al., 2007; Jana et al., 2017). The water stress resulted in significant decreases in chlorophyll content and the leaf relative water content (Naher, 2011). The maintenance of high plant water status and plant functions at low water potential, and the recovery of plant function after water stress are the major physiological processes that contribute to the maintenance of high yield under drought stress (Bouman and Tuong, 2001).

There is limited information on the difference in crop performance under continuous saturation along with other water management systems. Furthermore, physiological basis of yield gap among high yielding rice cultivars has not been studied extensively under Old Brahmaputra Floodplain ecosystem. Such information is vital for identifying the physiological and morphological traits to support the selection and breeding of high yielding rice cultivars. Efforts are few to address the growth, physiological responses and yield of rice (Oryza sativa L.) to water stress under tropical environment (Zain et al., 2014). Therefore, in this study, an attempt has been made to assess the influence of water stress as a measure of water saving technique during the subsequent growth period of crop ontogeny and yield.

\section{MATERIALS AND METHODS}

Site description: The experiment was conducted (using pots of $12.5-\mathrm{cm}$ diameter) in a glass house under controlled conditions in the Agronomy Department, Bangladesh Agricultural University, Mymensingh, Bangladesh (latitude: 244ㄴ $55^{\prime \prime}$, longitude: $90^{\circ} 25^{\prime} 47^{\prime \prime}$ ) during boro (dry) seasons of 2014-15. The experimental site (Mymensingh) is under a humid subtropical monsoon type of climate. The climate is humid subtropical monsoon. The mean minimum and maximum temperature and rainfall for the experimental period are shown in Figure 1. The physicochemical properties of the soil before the beginning of the experiment are shown in Table 1 .

Experimental design and treatments: Treatments consisting of five water management systems namely, continuous saturation (CS), water applications made 4, 6,8, 10 days after disappearance of $4 \mathrm{~cm}$ ponded water (DAD) and ten high yielding cultivars of rice viz., BRRI dhan28, BRRI dhan29, BRRI dhan47, BRRI dhan50, BRRI dhan59, BRRI dhan60, BRRI dhan61, Binadhan-8, Binadhan-10, and Binadhan-14.The selected cultivars were the most popular and high-yielding ones cultivated during the boro season. The experiment was conducted following completely randomized design (CRD) and replicated thrice. In each replication, 50 pots were placed side by side while maintaining 10 to $25 \mathrm{~cm}$ between them. The replicates were separated by $1 \mathrm{~m}$. The parentages of the cultivars tested including their import characteristics are presented (Table 2) to determine their adaptability with specific traits.

Pot preparation and fertilizer application: Each pot was filled with $8 \mathrm{~kg}$ of soil and placed in the glasshouse of the Department of Agronomy, BAU, Mymensingh. Extra water was applied to bring the soil moisture to a suitable level for seedlings because the pots were filled with dry soil. Two liters of water were added to saturate the soil. Fertilizer concentrations for pot experiments were applied as $2.7 \mathrm{~g}, 0.8 \mathrm{~g}, 1.04 \mathrm{~g}$, $0.9 \mathrm{~g}$, and $0.03 \mathrm{~g}$ per pot in the form of Urea, Triple Super Phosphate (TSP), Muriate of Potash (MOP), gypsum, and zinc sulfate, respectively. Whole amounts of fertilizers except Urea were applied during the final pot preparation. One-third of Urea $(0.9 \mathrm{~g})$ per pot was applied at 15 days after transplanting (DAT), 40 DAT, and 70 DAT.

Crop and water management: Forty days old seedlings (previously grown in the seedbed) of the cultivars were transplanted in the pot on January 12, 2015. There was $4 \mathrm{~cm}$ of standing water during transplanting and after disappearance of this ponded water, different water management treatments were applied. In the continuous saturation treatment, water as applied to saturate the soil (without flood), while for the other treatments, each irrigation was applied according to the time interval specified for the treatment. The irrigation was continued up to 15 days before the harvest of the crop. During the growth period, especially in the early stages, sometimes weeds were observed and uprooted by hand. No major insects were noticed except rice hispa during the growth period. The infestation was controlled by applying insecticides (Fenitrothion $50 \mathrm{EC}$ ) in each pot at the tillering stage.

Plant and growth dynamics measurement: In the experiment, phenological observations were done weekly. The anthesis date of rice was observed using the decimal code scale anticipated by Zadoks et al. (1974). Anthesis dates were recorded when $50 \%$ of the plants reached this periodin each plot. Observations on growth dynamics were made at active tillering (AT), panicle initiation (PI), flowering (FL), and physiological maturity (PM). The parameters to evaluate growth dynamics, such as plant height, leaf area index (LAI), crop growth rate (CGR), relative growth rate (RGR), and net assimilation rate (NAR) were recorded foreachpot through destructive sampling. For each destructive sample, a plant was uprooted and washed with water. The leaf blades were alienated from the leaf sheath and leaf area was measured by a leaf area meter (LI 3100, Licor, Inc., Lincoln NE, USA). Leaf area index was accordingly calculated from leaf area data. After measurement of leaf area, the plant samples were dried in an electric oven at $65^{\circ} \mathrm{C}$ for 72 hour until they reached at constant weight, and their dry weights were recorded. LAI, CGR, RGR, and NAR were calculated following the standard formulae (Radford, 1967; Hunt, 1978).

Biomass partitioning measurement: Biomass partitioning in the shape of sheath weight, leaf weight, root weight, and total dry matter was calculated for each water management treatment level for all cultivars. The sheath, leaf, and root dry weight was calculated during AT, PI, FL, and PM by placing the plant samples in the oven at $65^{\circ} \mathrm{C}$ for $72 \mathrm{~h}$. Total dry matter of the plant was determined by adding shoot dry matter, including leaf blade, leaf sheath, Culm, and panicle (when applicable) and root dry matter.

Estimation of irrigation water and water productivity: Amount of applied irrigated water was recorded from seedling establishment and continued up to 15 days before harvest. Water productivity of rice was calculated by dividing the total yield with the total amount of water required during entire crop growth period by following formula (Michael, 1978):

Water productivity $=\quad \frac{\mathrm{Y}}{\mathrm{WR}}\left(\mathrm{tha}^{-1} \mathrm{~cm}^{-1}\right)$
Where,

$\mathrm{Y}=$ grain yield $\left(\mathrm{t} \mathrm{ha}^{-1}\right), \mathrm{WR}=$ total amount of water used $(\mathrm{cm})$ 
Relative water Content (RWC) was calculated according to Smart and Bingham (1974):

$$
\mathrm{RWC}=\frac{\mathrm{FW}-\mathrm{DW}}{\mathrm{TW}-\mathrm{DW}} \times 100
$$

$\mathrm{FW}=$ Fresh leaf weight, $\mathrm{TW}=$ Turgid leaf weight, $\mathrm{DW}=\mathrm{Leaf}$ dry weight; For FW, fresh leaf sample was cut into a small disc and then fresh leaf weight was measured; For TW, the leaf sample (disc shaped) was soaked in distilled water for $4 \mathrm{hr}$ in the dark and thereafter the turgid leaf weight was measured and For DW, the leaf was dried at $80^{\circ} \mathrm{C}$ in an electric oven for $24 \mathrm{hr}$ and then weight was taken.

Measurement of yield and yield components: Maturity date was identified when $90 \%$ of grains had matured. At maturity, the whole plant was cut at the ground level with a sickle. The harvested crop from each pot was bundled separately and tagged appropriately. After recording data for plant height and panicle length for each plant, plant materials were sun dried for grain collection. Finally, grain and straw yield and yield contributing parameters were recorded separately.

\section{Data analysis}

Data on crop growth, yield components, and yield of rice were compiled and tabulated for statistical analysis. The recorded data on various plant characters were statistically analyzed to find out the significance of variation resulting from the experimental treatments. All the collected data were analyzed following analysis of variance (ANOVA) technique and mean differences were adjudged by Duncan's Multiple Range Test (Gomez and Gomez, 1984) using a computer operated program namely MSTAT-C.

\section{RESULTS AND DISCUSSION}

Crop phenology and environmental conditions during crop cycle: Crop duration was interactively determined by the cultivar and environment. Patterns for 10 cultivars with different phenology are shown in Figure 2. In the present study, the average length of life cycle of cultivars was 137 days (d). The greatest difference between the minimal and maximal crop duration for cultivars was $28 \mathrm{~d}$ and the smallest difference was $3 \mathrm{~d}$. Crop duration from emergence to FL varied from $92 \mathrm{~d}$ to $115 \mathrm{~d}$ depending on the cultivar. Grain filling duration exhibited variation based on cultivar from $26 \mathrm{~d}$ for Binadhan-14 to 33 for Binadhan-10. It was noted that the cultivar Binadhan10 matured much earlier than other cultivars along with more

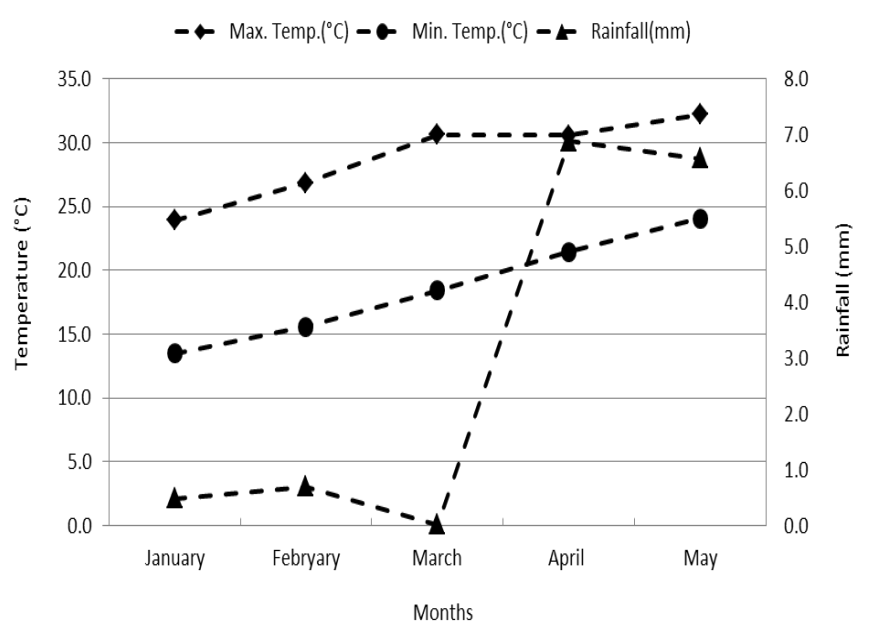

Figure 1. Temperature $\left({ }^{\circ} \mathrm{C}\right)$ pattern and mean rainfall $(\mathrm{mm})$ at the experimental site (Mymensingh, Bangladesh) during the experimental period. grain filling period. The rice cultivars having higher grain filling duration have produced higher yield (Yang et al., 2008). Extension of grain filling duration provided rice plant with more climatic resources such as temperature and solar radiation for prolonged grain growth.

Daily mean temperature for the effective grain-filling period was constant for all cultivars because of the relative stable temperature after FL (Figure 1). Considering phenology, during transplanting, PI, and FL daily mean temperatures were $17^{\circ} \mathrm{C}, 21^{\circ} \mathrm{C}$, and $24^{\circ} \mathrm{C}$, respectively. At the early stage of crop growth, there was no rainfall; however, at the grain-filling stage and onward, rainfall began, and maximum rainfall (46.6 $\mathrm{mm}$ ) was recorded during the grain-filling period (Figure 1).

Growth parameters: Significant $(\mathrm{P}<0.05)$ differences in terms of plant height among the cultivars were observed (Table 3). Cultivar BRRI dhan47 registered highest plant height $(93.85 \mathrm{~cm})$ while lowest was in Binadhan-14 (69.79 $\mathrm{cm})$. Plant height was also significantly $(\mathrm{P}<0.05)$ higher under different water management conditions (DAD) than under CS conditions. A significant reduction in plant height of under CS situation may be due to restriction of plant growth.

A significant variation in plant height and LAI at different growth stage based on cultivars and water management conditions are observed in Figures 3 and 4. Plant height increased progressively over time attaining the highest at PM. The rate of increase, however, varied depending on the growth stages. The cultivar Binadhan-10 recorded maximum plant height at all the growth stages except PM where Binadhan-8 showed highest value and both of which were statistically similar at this stage. The shortest plant height up to PM was observed with Binadhan-14. Among water management conditions, 8DAD treatment recorded the tallest plants at all the growth stages followed by 10- DAD. The shortest plant height was observed at CS at all the stages of growth except AT.

Cultivars differed significantly in respect of root dry weight $\mathrm{hill}^{-1}(\mathrm{~g})$ at FL. The highest root dry weight hill ${ }^{-1}(1.57 \mathrm{~g})$ was recorded in Binadhan-10 while being lowest in BRRI dhan61. Water management treatments also significantly affected root dry weight hill ${ }^{-1}$ at FL. It was enhanced compared to CS, but only in treatments up to 8 -DAD; beyond that, root dry weight was reduced. Panicle length differed significantly under both the cultivars and water management practices and among the cultivars, highest being in BRRI dhan29. Panicle length increased significantly up to 8 - DAD treatments compared to $\mathrm{CS}$ and then tended to decrease.

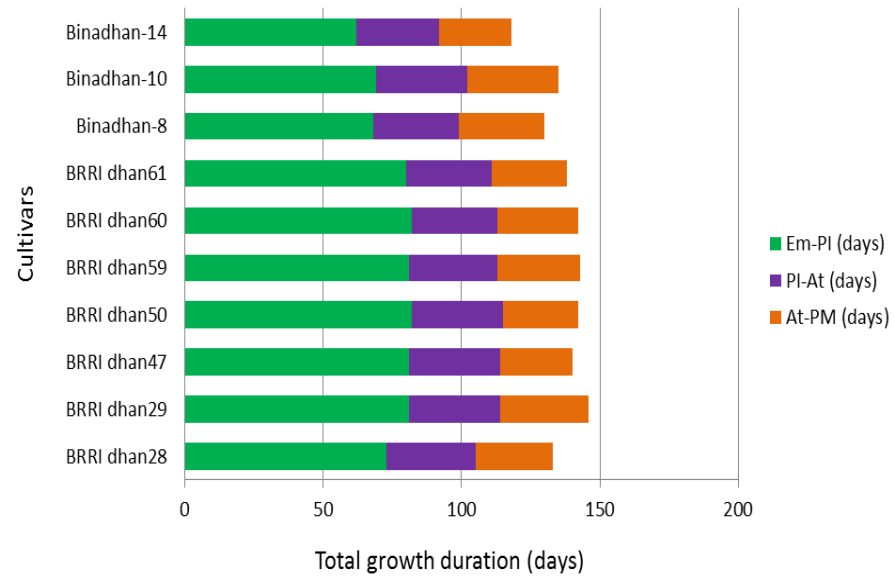

Figure 2. Crop phenology of high yielding rice cultivars of Bangladesh Bar shows the length of each development phase: Emergence (Em)-panicle initiation (PI) (green bars), PI-anthesis (At)( purple bar) and At-physiological maturity (PM) (orange). 

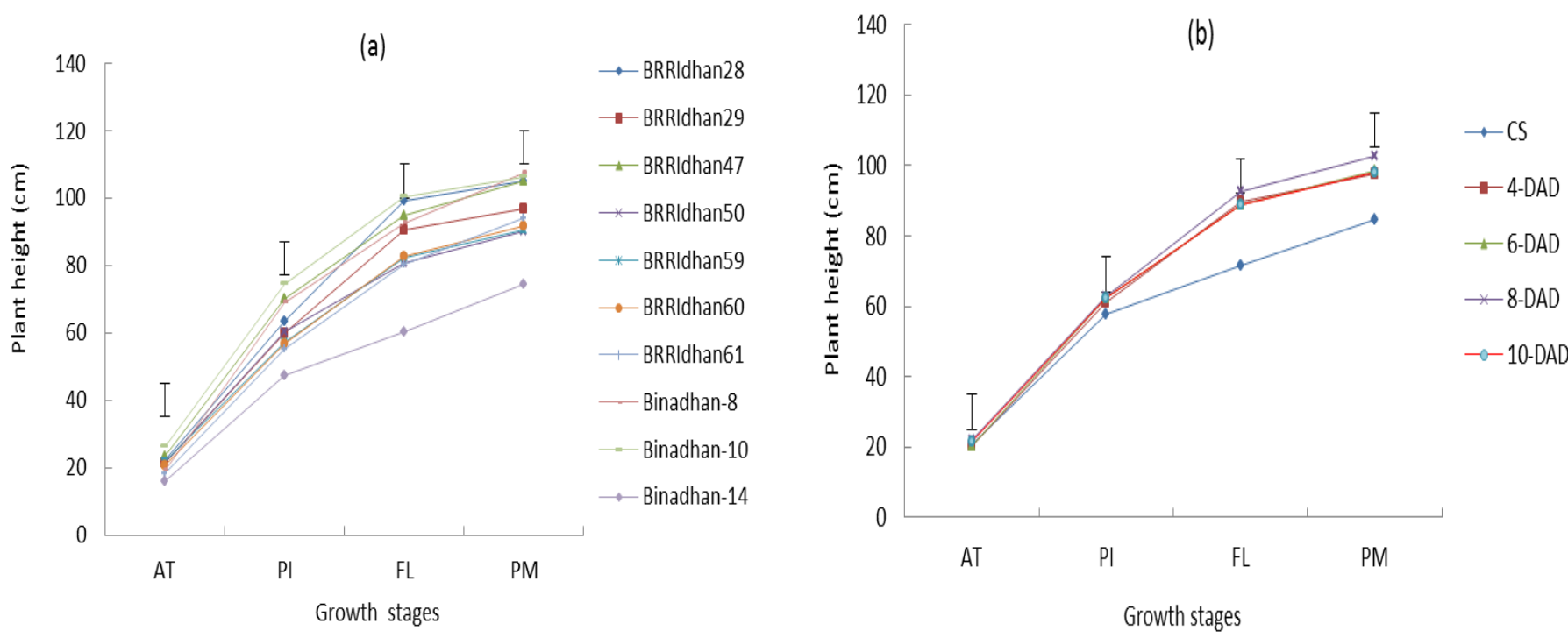

Figure 3. Plant height of rice as influenced by (a) cultivars (b) water management systems. Vertical bars represent LSD(P=0.05).
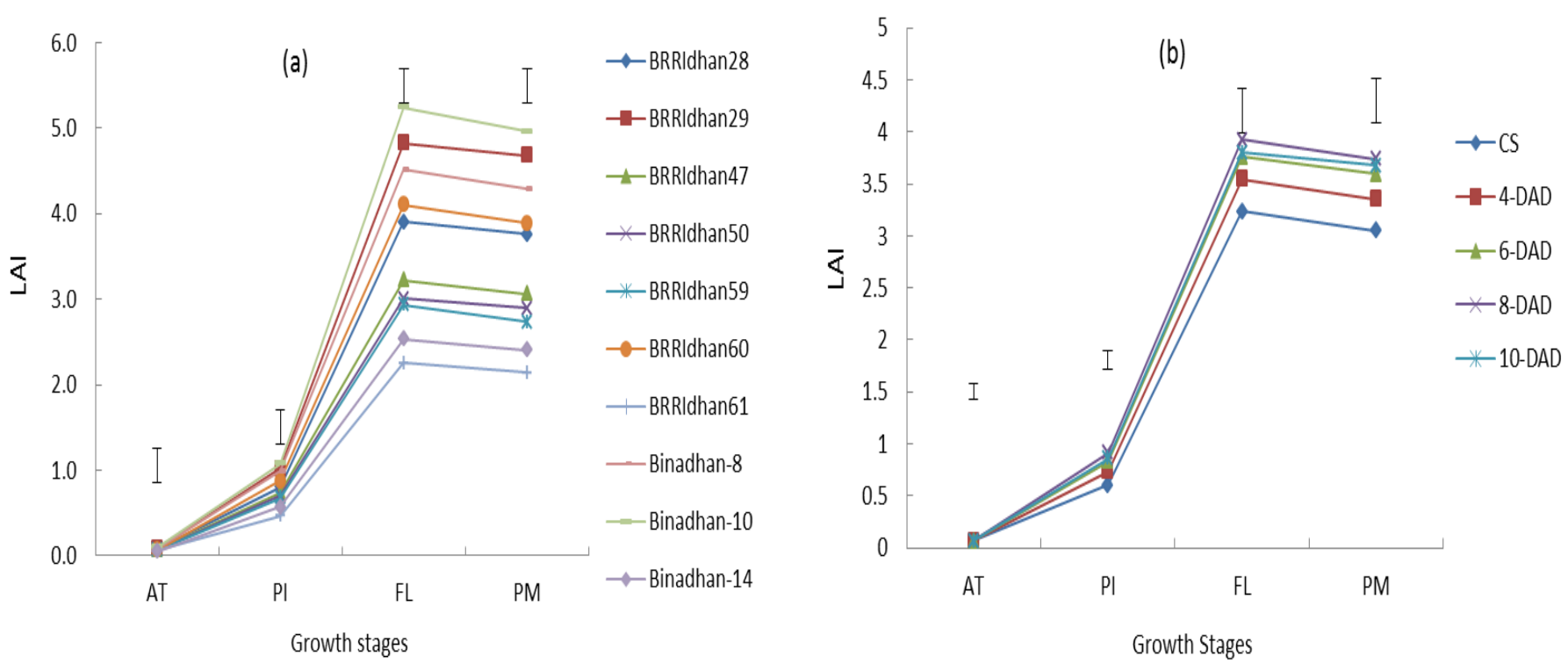

Figure 4. LAI of rice as influenced by (a) cultivars (b) water management systems. Vertical bars represent LSD(P=0.05).

TDM increased significantly with increasing plant growth started from AT to PM (TDM at FL only presented, Table 3). It was found significantly highest $(P<0.05)$ in Binadhan-10 followed by BRRI dhan29. The lowest TDM was observed in BRRI dhan61. A wide variability in photosynthetic rates exists in rice cultivars (Sharma and Singh, 1994) which may cause difference in dry matter accumulation. Alam et al. (2009) found differences in total dry matter accumulation in different genotypes. TDM ranged from 19.88 to 21.99 g plant $^{-}$ ${ }^{1}$ under different water management treatments.8-DAD treatment recorded significantly higher TDM compared to other DAD treatments and lowest TDM was observed under CS condition. Grain yield improvement of lowland rice cultivars released by the International Rice Research Institute (IRRI), Philippines is due to increases in biomass production (Peng et al, 1999). Akita (1989) and Amano et al. (1993) also stated that higher grain yield from rice was achieved by increasing biomass production.

LAI of rice cultivars with different levels of water management showed substantial differences over the growth stages. LAI is connected to biological and economic yields and enhance in LAI causes higher yield (Singh et al., 2009). Considering growth stage, LAI increased sharply reaching peak at FL and then decreased irrespective of treatment differ- ences. The rate of decrease of LAI after attaining peak was swifter. Maximum LAI (5.24) was attained at FL by Binadhan -10. Similarly, highest LAI was observed at all growth stages and at FL it was maximum (3.92) for 8-DAD treatments. LAI decreased after FL reflecting the loss of some existing leaves through senescence. A significant relationship $\left(\mathrm{R}^{2}=0.92\right.$, $P<0.01)$ between grain yield and LAI at FL is observed in Figure 5a. Cultivar having more LAI has the possibility to absorb more solar radiation, more photosynthesis and ultimately leads to higher yields.

Regarding CGR, it is observed that parallel to the increase in leaf area over the time, CGR also was raised until FL and then decreased (Table 4). CGR attained maximum of $22.60 \mathrm{~g} \mathrm{~cm}^{-2}$ day $^{-1}$ at FL for Binadhan-10 and minimum was noted at BRRI dhan61. CGR with 4-DAD, 6-DAD and 8-DAD was 7.14, 9.87 and $16.38 \%$ higher, respectively than CS treatments. Irrespective of treatments, RGR was more at early phase and showed a diminishing trend with the progress of plant age. The decline in RGR was possibly due to the raise of metabolically active tissue, which contributed less to the plant growth. Based on the trend of RGR in cultivars, it is stated that Binadhan-10 cultivar had the highest RGR at FL and after that BRRI dhan61 cultivars had the highest RGR at PM. The trend of NAR in both cultivars and water management 

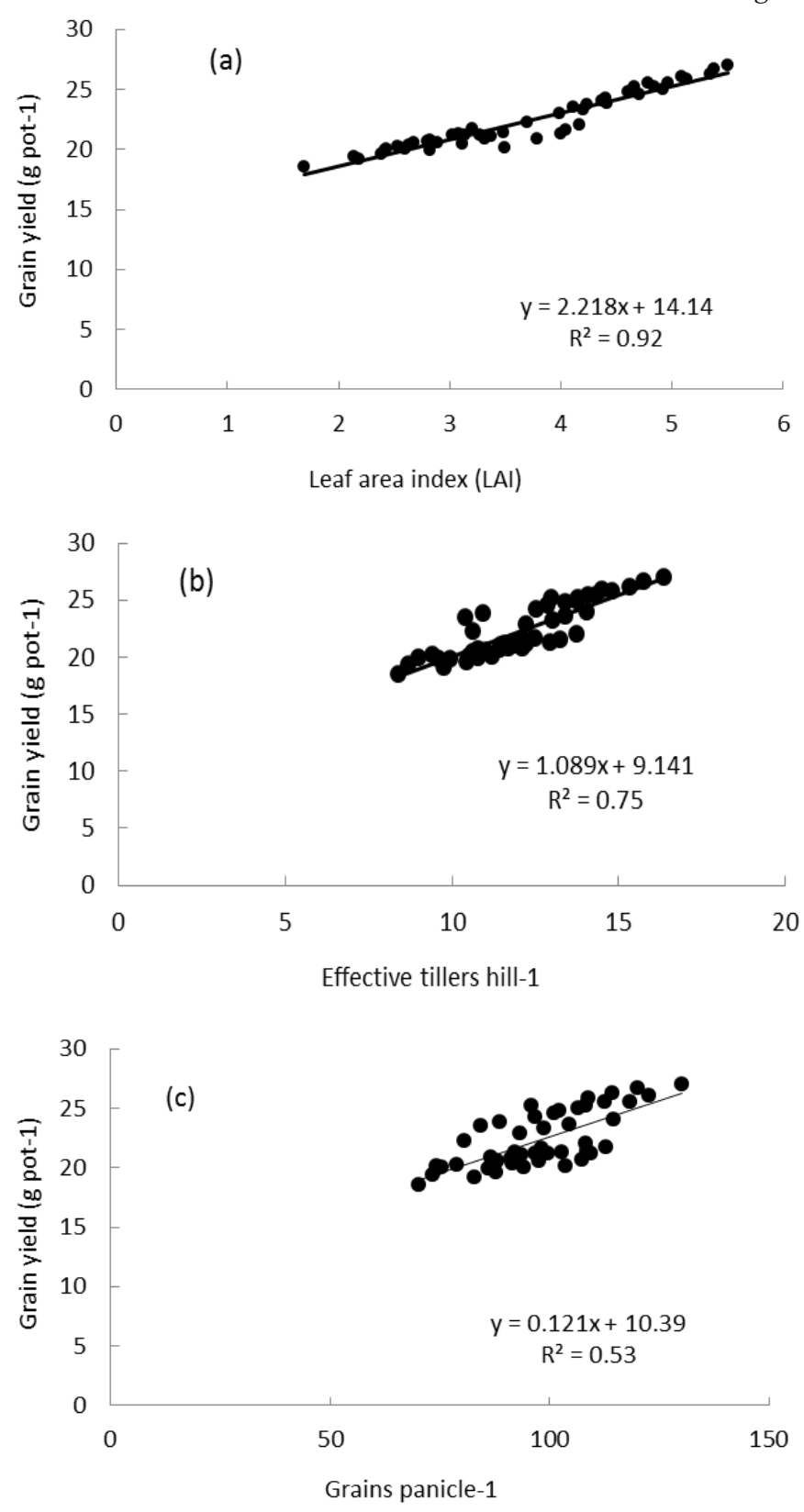

Figure 5. Relationship between grain yield and leaf area index (a) at flowering, effective tillers hill ${ }^{-1}$ (b) and grains panicle ${ }^{-1}$ (c) at harvest.

treatments was relatively equal and downward (Table 4). With LAI increasing, NAR was reduced in all the treatments and it can be due to the more tillering and leaf area development. The percentage of increase in NAR of 4-DAD, 6-DAD, 8DAD and 10-DAD were $5.83 \%, 10.37 \%, 11.99 \%$ and $14.03 \%$ respectively compared to $\mathrm{CS}$ at $\mathrm{PI}$.

Cultivars and water management systems has remarkable effect on RWC. The cultivars having the high RWC (\%) have the more capability of tolerance to drought condition. At FL, the highest RWC (91.51\%) was exhibited by Binadhan-10 and lowest RWC (82.06 \%) was recorded by BRRI dhan61. At FL and PM of water stress, most of the varieties had a little change in RWC and the similar patterns of RWC as before were observed. Water stress significant reduced RWC at vegetative and flowering stages after a certain period. The result indicated that, 8-DAD treatments showed highest RWC followed by 6-DAD and 4- DAD.

Yield attributes and yield: The cultivar Binadhan-10 produced highest number of effective tillers hill ${ }^{-1}$ closely followed by BRRI dhan 29 and Binadhan-8, whereas lowest number was noticed in BRRI dhan61 (Table 5). Grain yield variations for cultivars were significantly positively correlated $\left(\mathrm{R}^{2}=0.75\right.$, $\mathrm{p}<0.01$ ) with effective tillers hill ${ }^{-1}$ (Figure 5b).Similarly, number of grains panicle ${ }^{-1}$, grain yield and straw yield was higher in Binadhan-10. There was a significant positive correlation $\left(\mathrm{R}^{2}=0.52, \mathrm{p}<0.01\right)$ between grains panicle ${ }^{-1}$ and grain yield (Figure 5c). Binadhan-8 registered highest 1000 grain weight. A large number of studies have already been done on the relationships between yield components and yield in rice. There were positive correlations between yield and harvest index (HI), grain weight plant $^{-1}$, and grains panicle $^{-1}(\mathrm{Li}$ et al., 2005). Katsura et al. (2007) reported that rice yield is mainly dependent on producing ability of dry matter before heading. Moreover, grain number, which is the main part of sink size, is optimistically correlated with yield (Yoshida et al., 2006). In our study, the highest grain yield of Binahan-10 was related with more effective tillers hill $^{-1}$ and greater numbers of grains panicle $^{-1}$, but the higher grain yield of BRRI dhan 29 was mainly attributed to more panicle length. The results also suggest that biomass accumulated at FL has a great involvement to final yield performance. Evidently, the biomass gathered in the stems (and leaf sheath) will be transported into developing grains during filling stage.

Data on yield and yield attributes revealed that different water management (DAD) had significantly $(\mathrm{P}<0.05)$ higher values of yield attributes and yield compared to CS except 1000 grain weight and harvest index, which were non-significant for water management practices (Table 5). Grain yield of rice under 4- DAD, 6- DAD, 8- DAD treatments was 2.9\%, 4.9 $\%, 7.8 \%$ higher respectively than that recorded under CS condition. Beyond the 8- DAD treatments, the yield tended to decrease and it was $1.2 \%$ lower at 10 - DAD treatment compared to 8- DAD and it may be due to encountered moisture stress. The grain yield of rice under 8- DAD treatment was 7.8 $\%$ higher than CS condition. Grain yield difference between 8 -DAD and CS condition was also attributed primarily to the difference in sink formation (number of grains panicle ${ }^{-1}$ ), TDM accumulation and partly to difference in panicle length. Among yield components, sink size (number of grains panicle ${ }^{-1}$ ) contributed more towards grain yield and is the most important factor for minimizing yield difference between 8DAD and CS condition.

Interaction effect revealed that under different water management systems, Binadhan-10 recorded significantly higher yield over all the cultivars (Table 7). The cultivar BRRI dhan61 had lowest yield under different water management practices. Highest grain yield $\left(7.21 \mathrm{t} \mathrm{ha-}^{1}\right)$ was recorded in Binadhan-10 along with 8 -DAD treatments. The yield reduction ranges from $6.00 \%$ to $8.65 \%$ in CS condition compared to 8 -DAD treatment. This result showed that high yielding cultivars of rice are not suitable for CS condition.

Water requirement and productivity: Water use and water productivity under different water management treatments are shown in Table 6. Across all the water management treatments, irrigation water applied was maximum for CS (118 $\mathrm{cm})$ and minimum for treatment 10-DAD $(20 \mathrm{~cm})$ and 8-DAD $(24 \mathrm{~cm})$, respectively. These were $83 \%$ and $79.6 \%$ less water required for $10-\mathrm{DAD}$ and $8-\mathrm{DAD}$ compared to CS. Besides, the water productivity rice cultivars at $8-$ DAD and 10- DAD were $78.6 \%$ and $81.3 \%$ higher than that of the rice grown under CS condition. WUE of aerobic rice was higher compared to other establishment methods (Belder et al., 2007; Singh et al., 2008).This means that the water productivity decreased with the increase of irrigation water. Similar results are also reported by Islam and Mondal (1992). Among the treatments 
in which irrigation water applied, water productivity was the highest $\left(0.252 \mathrm{t} \mathrm{ha}^{-1} \mathrm{~cm}^{-1}\right)$ in treatment 10 -DAD and was found to be minimum $\left(0.047 \mathrm{t} \mathrm{ha}^{-1} \mathrm{~cm}^{-1}\right)$ in CS.

The adoption of AWD method means that application of irrigation water in fields to renovate flooded conditions on an intermittent basis, only after a certain number of days have passed since the disappearance of ponded (standing) water. The number of days of non-flooded soil before the subsequent irrigation is applied can differ from 1 day to more than 10 days under AWD (Bouman et al., 2007). In our study, most of the physiological and yield parameters showed better performance up to 8- DAD. The differences in the number of days between irrigations and in soil and hydrological conditions cause great variability in the results of AWD (Bouman and Tuong, 2001). However, beneficial effects from practicing AWD over continuous saturation apart from water saving have been reported exclusively. Continuous submergence was not crucial for achieving high rice yields (Sato and Uphoff, 2007). Yang et al. (2004) stated that AWD irrigation methods can produce greater and deeper root systems, enhancing nutrient uptake, raising water use efficiency and grain yield (Zhang et al., 2009). Yang et al. (2004) also reported that the positive responses of integrated nutrient management for rice yield are significantly declined by waterlogging of rice fields.

Table 1. Physicochemical properties of soil before start of the experiments.

\begin{tabular}{lc}
\hline Soil property & Values \\
\hline Soil texture & Clay loam \\
$\mathrm{pH}-\mathrm{H}_{2} \mathrm{O}$ & 5.83 \\
$\mathrm{EC}(\mu \mathrm{s} / \mathrm{cm})$ & 143 \\
Organic carbon (\%) & 1.125 \\
Total N (\%) & 0.145 \\
Available P (ppm) & 23.3 \\
Available K (ppm) & 88.64 \\
Available S (ppm) & 59.64 \\
\hline
\end{tabular}

Table 2. Parental line and significant characters of the rice cultivars tested in the experiment.

\begin{tabular}{|c|c|c|c|c|c|c|c|}
\hline S.N. & $\begin{array}{l}\text { Name of } \\
\text { cultivar }\end{array}$ & Parentage & $\begin{array}{c}\text { Year of } \\
\text { notification }\end{array}$ & $\begin{array}{c}\text { Duration } \\
\text { (days) }\end{array}$ & Ecosystem & Salient features & $\begin{array}{l}\text { Recommended } \\
\text { for cultivation }\end{array}$ \\
\hline 1. & $\begin{array}{c}\text { BRRI } \\
\text { dhan28 }\end{array}$ & $\begin{array}{l}\text { BR6 }(\text { IR28 }) \times \\
\text { Purbachi }\end{array}$ & 1994 & 140 & $\begin{array}{l}\text { Irrigated } \\
\text { lowland }\end{array}$ & $\begin{array}{l}\text { Early maturing and medium } \\
\text { slender grain, yield : } 6.0 \mathrm{t} / \mathrm{ha}\end{array}$ & $\begin{array}{c}\text { Sylhet, Netrakona } \\
\text { belt (flash flood } \\
\text { area) }\end{array}$ \\
\hline 2. & $\begin{array}{c}\text { BRRI } \\
\text { dhan29 }\end{array}$ & BG90-2 × BR51-46-5 & 1994 & 160 & Irrigated & $\begin{array}{l}\text { Very high yield potential and } \\
\text { medium slender grain, yield: } 7.5 \\
\text { t/ha }\end{array}$ & All Bangladesh \\
\hline 3. & $\begin{array}{c}\text { BRRI } \\
\text { dhan47 }\end{array}$ & $\begin{array}{l}\text { IR515111-B-B-34-B } \times \\
\text { TCCP266-2-49-B-B-3 }\end{array}$ & 2007 & 152 & Irrigated & $\begin{array}{l}\text { Salt tolerant and medium bold } \\
\text { grain, yield : } 6.0 \mathrm{t} / \mathrm{ha}\end{array}$ & $\begin{array}{l}\text { Barisal belt } \\
\text { (Saline area) }\end{array}$ \\
\hline 4. & $\begin{array}{l}\text { BRRI } \\
\text { dhan50 }\end{array}$ & $\mathrm{BR} 30 \times \mathrm{IR} 67684 \mathrm{~B}$ & 2008 & 155 & Irrigated & $\begin{array}{l}\text { Premium quality rice, slightly } \\
\text { aromatic } \\
\text { and long slender grain, yield: } \\
6.0 \mathrm{t} / \mathrm{ha}\end{array}$ & All Bangladesh \\
\hline 5. & $\begin{array}{c}\text { BRRI } \\
\text { dhan59 }\end{array}$ & $\begin{array}{l}\text { Collected from } \\
\text { International Network } \\
\text { for Germplasm } \\
\text { Evaluation of Rice } \\
\text { (INGER) }\end{array}$ & 2013 & 153 & Irrigated & $\begin{array}{l}\text { Dwarf, flag leaf erected and } \\
\text { deep green, non lodging and } \\
\text { medium bold grain, yield:7.1 t/ } \\
\text { ha }\end{array}$ & All Bangladesh \\
\hline 6. & $\begin{array}{l}\text { BRRI } \\
\text { dhan60 }\end{array}$ & BR7166-4-5-3 × BR26 & 2013 & 151 & Irrigated & $\begin{array}{l}\text { Lodging resistant and extra long } \\
\text { slender grain, yield : } 7.3 \mathrm{t} / \mathrm{ha}\end{array}$ & All Bangladesh \\
\hline 7. & $\begin{array}{c}\text { BRRI } \\
\text { dhan61 }\end{array}$ & $\begin{array}{l}\text { IR64419-3B-4-3 } \times \\
\text { BRRI dhan29 }\end{array}$ & 2013 & 150 & Irrigated & $\begin{array}{l}\text { Salt tolerant and medium slen- } \\
\text { der grain, yield : } 6.3 \mathrm{t} / \mathrm{ha}\end{array}$ & $\begin{array}{l}\text { Barisal belt } \\
\text { (Saline area) }\end{array}$ \\
\hline 8. & $\begin{array}{l}\text { Binadhan- } \\
\quad 8\end{array}$ & IR29 x Pokkali & 2010 & $130-135$ & Irrigated & $\begin{array}{l}\text { Semi dwarf, early maturing and } \\
\text { medium bold grain, salt tolerant, } \\
\text { yield: } 7.5-8.5 \mathrm{t} / \mathrm{ha}\end{array}$ & $\begin{array}{l}\text { Barisal belt } \\
\text { (Saline area) }\end{array}$ \\
\hline 9. & $\begin{array}{l}\text { Binadhan- } \\
\quad 10\end{array}$ & $\begin{array}{l}\text { IR42598-B-B-B-B-12 X } \\
\text { Nona Bokra }\end{array}$ & 2012 & $127-132$ & Irrigated & $\begin{array}{l}\text { Deep green and erect flag } \\
\text { leaves, trunks and stems are } \\
\text { strong, no lodging and no shat- } \\
\text { tering, salt tolerant, medium } \\
\text { long and slender grain, yield: } \\
7.5 \mathrm{t} / \mathrm{ha}\end{array}$ & $\begin{array}{l}\text { Barisal belt } \\
\text { (Saline area) }\end{array}$ \\
\hline 10. & $\begin{array}{l}\text { Binadhan- } \\
14\end{array}$ & $\begin{array}{l}\text { Ashfal mutant (Radiation } \\
\text { was applied on Ashfal) }\end{array}$ & 2013 & $120-130$ & Irrigated & $\begin{array}{l}\text { Shorter, erect and lodging re- } \\
\text { sistant, late planting, long and } \\
\text { slender grain, yield: } 6.85 \mathrm{t} / \mathrm{ha}\end{array}$ & All Bangladesh \\
\hline
\end{tabular}


Table 3. Growth parameters of rice as influenced by cultivar and water management systems.

\begin{tabular}{|c|c|c|c|c|}
\hline Treatments & Plant height (cm) & Root dry weight $/$ hill $^{-1}$ (g) & Panicle length (cm) & Total dry matter $\left(\mathrm{g} \mathrm{plant}^{-1}\right)$ \\
\hline \multicolumn{5}{|l|}{ Cultivars (C) } \\
\hline BRRI dhan28 & $78.28 \mathrm{~g}$ & $1.16 \mathrm{e}$ & $22.24 \mathrm{c}$ & $21.73 \mathrm{e}$ \\
\hline BRRI dhan29 & $80.40 \mathrm{f}$ & $1.45 \mathrm{~b}$ & $24.91 \mathrm{a}$ & $26.88 \mathrm{~b}$ \\
\hline BRRI dhan47 & $93.85 \mathrm{a}$ & $0.95 f$ & $21.17 \mathrm{~d}$ & $17.92 \mathrm{f}$ \\
\hline BRRI dhan50 & $72.03 \mathrm{i}$ & $0.89 \mathrm{~g}$ & $21.19 d$ & $16.68 \mathrm{~g}$ \\
\hline BRRI dhan59 & $73.14 \mathrm{~h}$ & $0.86 \mathrm{~g}$ & $21.43 d$ & $16.29 \mathrm{~g}$ \\
\hline BRRI dhan 60 & $82.84 d$ & $1.22 \mathrm{~d}$ & $22.54 \mathrm{c}$ & $22.84 \mathrm{~d}$ \\
\hline BRRI dhan61 & $81.47 \mathrm{e}$ & $0.65 \mathrm{i}$ & $19.96 \mathrm{f}$ & $12.68 \mathrm{i}$ \\
\hline Binadhan-8 & $85.68 \mathrm{c}$ & $1.35 \mathrm{c}$ & $23.74 b$ & $25.15 \mathrm{c}$ \\
\hline Binadhan-10 & $88.49 b$ & $1.57 \mathrm{a}$ & $23.96 b$ & $29.22 \mathrm{a}$ \\
\hline Binadhan-14 & $69.79 \mathrm{j}$ & $0.74 \mathrm{~h}$ & $20.49 \mathrm{e}$ & $14.06 \mathrm{~h}$ \\
\hline \multicolumn{5}{|l|}{ Water management $(\mathrm{W})$} \\
\hline $\mathrm{CS}$ & $79.60 \mathrm{~b}$ & $0.99 \mathrm{~d}$ & $21.11 \mathrm{e}$ & $18.27 \mathrm{~d}$ \\
\hline 4 -DAD & $80.50 \mathrm{a}$ & $1.09 \mathrm{c}$ & $21.64 d$ & $19.88 \mathrm{c}$ \\
\hline 6 - DAD & $80.94 a$ & $1.15 \mathrm{~b}$ & $22.26 \mathrm{c}$ & $20.56 b$ \\
\hline 8-DAD & $81.00 \mathrm{a}$ & $1.20 \mathrm{a}$ & $23.16 \mathrm{a}$ & $21.99 \mathrm{a}$ \\
\hline $10-\mathrm{DAD}$ & $80.95 a$ & $1.00 \mathrm{~d}$ & $22.63 b$ & $21.02 \mathrm{~b}$ \\
\hline \multicolumn{5}{|l|}{ ANOVA } \\
\hline Cultivars (V) & ** & $* *$ & $* *$ & $* *$ \\
\hline Water management $(\mathrm{W})$ & $* *$ & $* *$ & ** & $* *$ \\
\hline $\mathrm{V} \times \mathrm{W}$ & NS & NS & NS & NS \\
\hline CV (\%) & 1.77 & 5.38 & 3.18 & 5.20 \\
\hline
\end{tabular}

Within a column, means followed by same letters are not significantly different at $5 \%$ probability level by Duncan's Multiple Range Test (DMRT); ** Significant difference at $\mathrm{P} \leq 0.01$, NS- Non-significant.

Table 4. Physiological and bio-chemical parameters of rice as influenced by cultivar and water management systems.

\begin{tabular}{|c|c|c|c|c|c|c|c|c|c|c|c|c|c|}
\hline \multirow{2}{*}{ Treatments } & \multicolumn{3}{|c|}{ CGR $\left(\mathrm{g} \mathrm{cm}^{-2} \mathrm{day}^{-1}\right)$} & \multicolumn{3}{|c|}{ RGR ( $\left(g^{-1} g^{-1}\right.$ day $)$} & \multicolumn{3}{|c|}{ NAR $\left(\mathrm{mg} \mathrm{cm}^{-2} \mathrm{day}^{-1}\right)$} & \multicolumn{4}{|c|}{ RWC (\%) } \\
\hline & AT-PI & PI-FL & FL-PM & AT-PI & PI-FL & FL-PM & AT-PI & PI-FL & FL-PM & AT & PI & FL & $\mathbf{P M}$ \\
\hline \multicolumn{14}{|l|}{ Cultivars (C) } \\
\hline $\begin{array}{c}\text { BRRI } \\
\text { dhan28 }\end{array}$ & $2.30 \mathrm{e}$ & $16.75 \mathrm{e}$ & $8.09 \mathrm{~cd}$ & $47.20 \mathrm{de}$ & $35.82 \mathrm{ab}$ & $6.09 \mathrm{e}$ & $0.3340 \mathrm{abc}$ & 0.3727 & $0.0913 \mathrm{de}$ & $90.20 \mathrm{ab}$ & $85.43 \mathrm{~d}$ & $88.86 \mathrm{abc}$ & $87.24 \mathrm{ab}$ \\
\hline $\begin{array}{c}\text { BRRI } \\
\text { dhan29 }\end{array}$ & $2.90 \mathrm{~b}$ & $20.69 b$ & $8.72 b c$ & $48.85 \mathrm{bc}$ & $35.54 \mathrm{abc}$ & $5.42 \mathrm{~g}$ & $0.3413 \mathrm{abc}$ & 0.3687 & $0.0813 \mathrm{e}$ & $91.26 \mathrm{ab}$ & $85.77 \mathrm{~d}$ & $90.82 \mathrm{a}$ & $89.45 \mathrm{a}$ \\
\hline $\begin{array}{c}\text { BRRI } \\
\text { dhan47 }\end{array}$ & $2.06 f$ & $13.64 \mathrm{f}$ & $7.33 \mathrm{~d}$ & $46.74 \mathrm{ef}$ & $34.39 \mathrm{~b}-\mathrm{e}$ & $6.60 \mathrm{~d}$ & $0.3260 \mathrm{bc}$ & 0.3553 & $0.1020 \mathrm{~cd}$ & $90.04 \mathrm{ab}$ & $88.52 a-d$ & $86.76 \mathrm{bcd}$ & $84.87 \mathrm{bc}$ \\
\hline $\begin{array}{c}\text { BRRI } \\
\text { dhan50 }\end{array}$ & $1.94 \mathrm{~g}$ & $12.66 \mathrm{~g}$ & $7.51 \mathrm{~d}$ & $46.29 \mathrm{efg}$ & $34.19 \mathrm{cde}$ & $7.17 \mathrm{c}$ & $0.3187 \mathrm{c}$ & 0.3513 & $0.1107 \mathrm{bc}$ & $89.74 a b$ & $88.31 \mathrm{a}-\mathrm{d}$ & $85.88 \mathrm{~cd}$ & $83.90 \mathrm{~cd}$ \\
\hline $\begin{array}{c}\text { BRRI } \\
\text { dhan59 }\end{array}$ & $1.87 \mathrm{~g}$ & $12.39 \mathrm{~g}$ & $7.53 \mathrm{~d}$ & $45.37 \mathrm{~g}$ & $34.31 \mathrm{~b}-\mathrm{e}$ & $7.33 \mathrm{c}$ & $0.3193 \mathrm{c}$ & 0.3527 & $0.1160 \mathrm{~b}$ & $88.93 b$ & $89.96 \mathrm{ab}$ & $85.61 \mathrm{~cd}$ & $83.56 \mathrm{~cd}$ \\
\hline $\begin{array}{c}\text { BRRI } \\
\text { dhan60 }\end{array}$ & $2.48 \mathrm{~d}$ & $17.57 \mathrm{~d}$ & $7.91 \mathrm{~cd}$ & $50.40 \mathrm{a}$ & $35.57 \mathrm{abc}$ & $5.71 \mathrm{f}$ & $0.3480 \mathrm{ab}$ & 0.3687 & $0.0846 \mathrm{e}$ & $92.08 \mathrm{a}$ & $89.52 \mathrm{abc}$ & $89.36 \mathrm{ab}$ & 87.79ab \\
\hline $\begin{array}{c}\text { BRRI } \\
\text { dhan61 }\end{array}$ & $1.51 \mathrm{i}$ & $9.579 \mathrm{i}$ & $7.05 \mathrm{~d}$ & $45.67 \mathrm{~g}$ & 33.66de & $8.53 \mathrm{a}$ & $0.3500 \mathrm{ab}$ & 0.3633 & $0.1393 a$ & $88.94 b$ & $91.08 \mathrm{a}$ & $82.06 \mathrm{e}$ & $79.64 \mathrm{e}$ \\
\hline Binadhan-8 & $2.79 \mathrm{c}$ & $19.27 \mathrm{c}$ & 9.39ab & $47.96 \mathrm{~cd}$ & $35.08 \mathrm{a}-\mathrm{d}$ & $6.11 \mathrm{e}$ & $0.3347 \mathrm{abc}$ & 0.3620 & $0.0926 \mathrm{de}$ & $90.68 \mathrm{ab}$ & $89.88 \mathrm{ab}$ & $90.24 \mathrm{a}$ & $88.80 \mathrm{a}$ \\
\hline Binadhan-10 & $3.02 \mathrm{a}$ & $22.60 \mathrm{a}$ & $10.16 \mathrm{a}$ & $45.90 \mathrm{fg}$ & $36.13 \mathrm{a}$ & $5.75 \mathrm{f}$ & $0.3207 \mathrm{c}$ & 0.3760 & $0.0873 \mathrm{e}$ & $89.49 b$ & $86.30 \mathrm{~cd}$ & $91.51 \mathrm{a}$ & $90.22 \mathrm{a}$ \\
\hline Binadhan-14 & $1.73 \mathrm{~h}$ & $10.59 \mathrm{~h}$ & $7.37 \mathrm{~d}$ & $49.16 \mathrm{~b}$ & $33.30 \mathrm{e}$ & $8.10 \mathrm{~b}$ & $0.3547 \mathrm{a}$ & 0.3487 & $0.1293 \mathrm{a}$ & $91.41 \mathrm{ab}$ & $86.78 \mathrm{bcd}$ & 83.61de & $81.35 \mathrm{de}$ \\
\hline \multicolumn{14}{|l|}{$\begin{array}{c}\text { Water } \\
\text { management } \\
\text { (W) }\end{array}$} \\
\hline $\mathrm{CS}$ & $1.72 \mathrm{e}$ & $14.29 \mathrm{~d}$ & $7.04 b$ & $44.63 \mathrm{~d}$ & $37.12 \mathrm{a}$ & $6.59 \mathrm{bc}$ & $0.3087 \mathrm{c}$ & $0.3893 \mathrm{a}$ & 0.1043 & $87.95 \mathrm{c}$ & $89.20 \mathrm{a}$ & $85.65 b$ & $83.71 \mathrm{c}$ \\
\hline 4-DAD & $2.12 \mathrm{~d}$ & $15.31 \mathrm{c}$ & $7.63 b$ & $47.20 \mathrm{~b}$ & $35.55 \mathrm{~b}$ & $6.52 \mathrm{c}$ & $0.3267 b$ & $0.3733 \mathrm{a}$ & 0.1017 & $90.53 b$ & $87.13 \mathrm{ab}$ & $87.74 a b$ & $85.96 \mathrm{abc}$ \\
\hline 6-DAD & $2.34 \mathrm{c}$ & $15.70 \mathrm{bc}$ & $8.44 \mathrm{a}$ & $49.31 \mathrm{a}$ & $34.18 \mathrm{c}$ & $6.83 a$ & $0.3407 \mathrm{ab}$ & $0.3480 \mathrm{~b}$ & 0.1043 & $91.79 \mathrm{ab}$ & $89.20 \mathrm{a}$ & $88.42 \mathrm{a}$ & $86.72 \mathrm{ab}$ \\
\hline 8-DAD & $2.63 \mathrm{a}$ & $16.63 \mathrm{a}$ & $8.95 \mathrm{a}$ & $45.94 \mathrm{c}$ & $33.57 \mathrm{c}$ & $6.75 \mathrm{ab}$ & $0.3457 \mathrm{a}$ & $0.3513 b$ & 0.1050 & $92.16 \mathrm{a}$ & $89.19 \mathrm{a}$ & $88.90 \mathrm{a}$ & $87.2 \mathrm{a}$ \\
\hline 10-DAD & $2.50 \mathrm{~b}$ & $15.94 b$ & $8.47 \mathrm{a}$ & $49.69 \mathrm{a}$ & $33.58 \mathrm{c}$ & $6.71 \mathrm{abc}$ & $0.3520 \mathrm{a}$ & $0.3477 \mathrm{~b}$ & 0.1020 & $88.95 \mathrm{c}$ & $86.04 \mathrm{~b}$ & $86.65 \mathrm{ab}$ & $84.75 b c$ \\
\hline \multicolumn{14}{|l|}{ ANOVA } \\
\hline $\begin{array}{l}\text { Cultivars } \\
\text { (V) }\end{array}$ & $* *$ & $* *$ & $* *$ & $* *$ & $* *$ & $* *$ & $* *$ & NS & $* *$ & $*$ & $* *$ & $* *$ & $* *$ \\
\hline $\begin{array}{c}\text { Water } \\
\text { management } \\
\text { (W) }\end{array}$ & $* *$ & $* *$ & $* *$ & $* *$ & $* *$ & $* *$ & $* *$ & $* *$ & NS & $* *$ & $* *$ & $*$ & $* *$ \\
\hline $\mathrm{V} \times \mathrm{W}$ & $* *$ & NS & NS & $* *$ & $* *$ & $* *$ & NS & NS & NS & NS & NS & NS & NS \\
\hline CV (\%) & 4.39 & 6.68 & 15.66 & 2.82 & 5.46 & 5.36 & 9.10 & 10.08 & 16.57 & 3.25 & 4.81 & 4.97 & 5.09 \\
\hline
\end{tabular}

Within a column, means followed by same letters are not significantly different at $5 \%$ probability level by Duncan's Multiple Range Test (DMRT); $A T$ active tillering, $P I$ panicle initiation, $F l$ flowering, $P M$ physiological maturity, $C G R$ crop growth rate, $R G R$ relative growth rate, ,NAR net assimilation rate, $R W C$ relative water content $*$ Significant difference at $\mathrm{P} \leq 0.05, * *$ Significant difference at $\mathrm{P} \leq 0.01$, NS- Non-significant. 
Table 5. Yields attributes and yield of rice as influenced by cultivar and water management systems.

\begin{tabular}{|c|c|c|c|c|c|c|}
\hline Treatments & $\begin{array}{c}\text { Effective tillers } \\
\text { hill }^{-1}\end{array}$ & $\begin{array}{c}\text { No. of grains } \\
\text { panicle }^{-1}\end{array}$ & $\begin{array}{l}1000 \text { grain } \\
\text { weight }(g)\end{array}$ & $\begin{array}{l}\text { Grain yield } \\
\left(\operatorname{g~pot}^{-1}\right)^{\mathrm{a}}\end{array}$ & $\begin{array}{c}\text { Straw yield (g } \\
\left.\text { pot }^{-1}\right)^{\mathbf{a}}\end{array}$ & $\begin{array}{c}\text { Harvest } \\
\text { Index (\%) }\end{array}$ \\
\hline \multicolumn{7}{|l|}{ Cultivars (C) } \\
\hline BRRI dhan28 & $12.50 \mathrm{c}$ & $91.90 \mathrm{e}$ & $20.45 \mathrm{e}$ & $21.17 \mathrm{~d}$ & $21.32 \mathrm{~d}$ & 49.85 \\
\hline BRRI dhan29 & $13.22 \mathrm{~b}$ & $106.4 \mathrm{~b}$ & $21.77 \mathrm{~d}$ & $24.99 \mathrm{~b}$ & $25.33 \mathrm{~b}$ & 49.65 \\
\hline BRRI dhan47 & $11.26 \mathrm{~d}$ & $92.30 \mathrm{e}$ & $25.85 \mathrm{~b}$ & $20.74 \mathrm{de}$ & $20.97 \mathrm{de}$ & 49.75 \\
\hline BRRI dhan50 & $11.01 \mathrm{~d}$ & $93.27 \mathrm{e}$ & $17.26 \mathrm{f}$ & 20.79 de & $20.97 \mathrm{de}$ & 49.83 \\
\hline BRRI dhan59 & $11.24 \mathrm{~d}$ & $96.63 \mathrm{~d}$ & $20.54 \mathrm{e}$ & $21.02 \mathrm{~d}$ & 20.95 de & 50.11 \\
\hline BRRI dhan60 & $12.64 \mathrm{bc}$ & $98.40 \mathrm{~d}$ & $23.35 \mathrm{c}$ & $23.23 \mathrm{c}$ & $23.57 \mathrm{c}$ & 49.63 \\
\hline BRRI dhan61 & $10.10 \mathrm{e}$ & $87.81 \mathrm{f}$ & $20.53 \mathrm{e}$ & $19.47 \mathrm{f}$ & $20.03 \mathrm{f}$ & 49.29 \\
\hline Binadhan-8 & $12.88 \mathrm{bc}$ & $102.0 \mathrm{c}$ & $27.55 \mathrm{a}$ & $24.65 \mathrm{~b}$ & $25.38 \mathrm{~b}$ & 49.28 \\
\hline Binadhan-10 & $15.03 \mathrm{a}$ & 113.9 a & $26.27 \mathrm{~b}$ & $26.19 \mathrm{a}$ & $26.65 \mathrm{a}$ & 49.56 \\
\hline Binadhan-14 & $10.34 \mathrm{e}$ & $91.23 \mathrm{e}$ & $21.20 \mathrm{de}$ & $20.17 \mathrm{e}$ & $20.52 \mathrm{ef}$ & 49.54 \\
\hline \multicolumn{7}{|l|}{ Water management $(\mathrm{W})$} \\
\hline $\mathrm{CS}$ & $10.04 \mathrm{~d}$ & $79.69 \mathrm{e}$ & 22.30 & $21.30 \mathrm{~d}$ & $21.47 \mathrm{~d}$ & 49.82 \\
\hline 4 -DAD & $11.65 \mathrm{c}$ & $92.22 \mathrm{~d}$ & 22.47 & $21.91 \mathrm{c}$ & $22.03 \mathrm{c}$ & 49.87 \\
\hline 6 - DAD & $12.42 \mathrm{~b}$ & $97.68 \mathrm{c}$ & 22.36 & $22.36 \mathrm{bc}$ & $22.52 \mathrm{c}$ & 49.83 \\
\hline 8-DAD & $13.24 \mathrm{a}$ & $113.6 \mathrm{a}$ & 22.91 & $22.96 \mathrm{a}$ & $23.80 \mathrm{a}$ & 49.14 \\
\hline 10 - DAD & $12.76 \mathrm{~b}$ & $103.7 \mathrm{~b}$ & 22.34 & $22.68 \mathrm{ab}$ & $23.04 \mathrm{~b}$ & 49.60 \\
\hline \multicolumn{7}{|l|}{ ANOVA } \\
\hline Cultivars (V) & $* *$ & $* *$ & $* *$ & $* *$ & $* *$ & NS \\
\hline Water management (W) & $* *$ & $* *$ & NS & $* *$ & $* *$ & NS \\
\hline $\mathrm{V} \times \mathrm{W}$ & NS & NS & NS & NS & NS & NS \\
\hline $\mathrm{CV}(\%)$ & 7.17 & 3.59 & 6.95 & 3.97 & 4.22 & 2.94 \\
\hline
\end{tabular}

Within a column, means followed by same letters are not significantly different at $5 \%$ probability level by Duncan's Multiple Range Test (DMRT) ** Significant difference at $\mathrm{P} \leq 0.01$, NS- Non-significant; Grain yield and straw yield are at $14 \%$ moisture content.

Table 6. Water use and water productivity under different water management systems.

\begin{tabular}{|c|c|c|c|c|c|c|c|}
\hline Treatments & $\begin{array}{c}\text { No. of } \\
\text { irrigations }\end{array}$ & $\begin{array}{l}\text { Frequency of } \\
\text { water } \\
\text { application } \\
\text { (DAT) }\end{array}$ & $\begin{array}{l}\text { Water used for } \\
\text { crop } \\
\text { establishment } \\
\quad(\mathrm{cm})\end{array}$ & $\begin{array}{l}\text { Irrigation } \\
\text { water } \\
\text { applied } \\
\text { (cm) }\end{array}$ & $\begin{array}{c}\text { Total } \\
\text { water } \\
\text { use } \\
(\mathrm{cm})\end{array}$ & $\begin{array}{c}\text { Grain yield } \\
\left(t \mathrm{ha}^{-1}\right)\end{array}$ & $\begin{array}{c}\text { Water } \\
\text { productivity } \\
\left(\mathrm{t} \mathrm{ha}^{-1} \mathrm{~cm}^{-1}\right)\end{array}$ \\
\hline $\mathrm{CS}$ & $\begin{array}{l}\text { Continuous } \\
\text { saturation }\end{array}$ & $\begin{array}{c}\text { Every } \\
\text { alternate day }\end{array}$ & 4 & 118 & 122 & $5.687 \mathrm{~d}$ & 0.047 \\
\hline 4 -DAD & 10 & $\begin{array}{c}30,36,42,48 \\
54,60,66,72 \\
78,84\end{array}$ & 4 & 40 & 44 & $5.851 \mathrm{c}$ & 0.133 \\
\hline 6 - DAD & 8 & $\begin{array}{c}30,38,46,54 \\
62,70,78,86\end{array}$ & 4 & 32 & 36 & $5.970 \mathrm{bc}$ & 0.166 \\
\hline 8-DAD & 6 & $\begin{array}{c}30,40,50,60 \\
70,80\end{array}$ & 4 & 24 & 28 & $6.130 \mathrm{a}$ & 0.219 \\
\hline $10-\mathrm{DAD}$ & 5 & $\begin{array}{c}30,42 \\
54,66,78\end{array}$ & 4 & 20 & 24 & $6.055 \mathrm{ab}$ & 0.252 \\
\hline Level of significance & & & & & & $* *$ & \\
\hline CV (\%) & & & & & & 3.97 & \\
\hline
\end{tabular}

Within a column, means followed by same letters are not significantly different at $5 \%$ probability level by Duncan's Multiple Range Test (DMRT); **

Significant difference at $\mathrm{P} \leq 0.01$ 
Table 7. Interaction between cultivars and water management systems on grain yield and water productivity.

\begin{tabular}{|c|c|c|c|c|c|c|c|c|c|c|c|}
\hline \multirow{2}{*}{ Cultivars } & \multicolumn{5}{|c|}{ Grain yield $\left(\mathrm{t} \mathrm{ha}^{-1}\right)$} & \multirow{2}{*}{$\begin{array}{c}\% \text { yield } \\
\text { reduction }^{\mathrm{a}}\end{array}$} & \multicolumn{5}{|c|}{ Water productivity $\left(\mathrm{t} \mathrm{ha}^{-1} \mathrm{~cm}^{-1}\right)$} \\
\hline & CS & 4-DAD & 6- DAD & 8-DAD & 10-DAD & & CS & 4-DAD & 6- DAD & 8-DAD & 10-DAD \\
\hline BRRI dhan 28 & 5.38 & 5.57 & 5.68 & 5.87 & 5.76 & 8.35 & 0.044 & 0.127 & 0.158 & 0.210 & 0.240 \\
\hline BRRI dhan29 & 6.37 & 6.56 & 6.67 & 6.94 & 6.81 & 8.65 & 0.052 & 0.149 & 0.185 & 0.248 & 0.284 \\
\hline BRRI dhan 47 & 5.32 & 5.46 & 5.57 & 5.71 & 5.62 & 6.83 & 0.044 & 0.124 & 0.155 & 0.204 & 0.234 \\
\hline BRRI dhan50 & 5.33 & 5.47 & 5.62 & 5.67 & 5.66 & 6.00 & 0.044 & 0.124 & 0.156 & 0.203 & 0.236 \\
\hline BRRI dhan59 & 5.39 & 5.54 & 5.65 & 5.79 & 5.70 & 6.91 & 0.044 & 0.126 & 0.157 & 0.207 & 0.238 \\
\hline BRRI dhan60 & 5.94 & 6.12 & 6.21 & 6.41 & 6.32 & 7.33 & 0.049 & 0.139 & 0.173 & 0.229 & 0.263 \\
\hline BRRI dhan61 & 4.95 & 5.12 & 5.22 & 5.37 & 5.34 & 7.82 & 0.041 & 0.116 & 0.145 & 0.192 & 0.223 \\
\hline Binadhan-8 & 6.28 & 6.47 & 6.63 & 6.81 & 6.72 & 7.78 & 0.052 & 0.147 & 0.184 & 0.243 & 0.280 \\
\hline Binadhan-10 & 6.72 & 6.89 & 7.01 & 7.21 & 7.14 & 6.80 & 0.055 & 0.157 & 0.194 & 0.258 & 0.298 \\
\hline Binadhan-14 & 5.18 & 5.30 & 5.43 & 5.52 & 5.49 & 6.16 & 0.043 & 0.121 & 0.151 & 0.197 & 0.229 \\
\hline $\begin{array}{c}\text { Level of } \\
\text { significance }\end{array}$ & NS & NS & NS & NS & NS & & & & & & \\
\hline
\end{tabular}

Within a column, means followed by same letters are not significantly different at $5 \%$ probability level by Duncan's Multiple Range Test (DMRT) NS- Nonsignificant; ${ }^{\mathrm{a}}$ Compared to 8-DAD treatment.

\section{Conclusions}

It is obvious from these results that the cultivar Binadhan-10 with high values of physiological, yield contributing and yield parameters appears to best choice for periodic water stress condition. The cultivar BRRI dhan29 was the next best after Binadhan-10 for cultivation in such condition. The physiological attributes of these two cultivars may be used for breeding a cultivar for a particular environment. On the other hand, AWD had beneficial effects on grain yield compared with CS. Continuous standing water in the rice field, which is a usual practice in Bangladesh, was not found to give optimum yield. The highest grain yield was obtained from 8 -DAD and greatest water productivity was found with the 10 -DAD treatment. This indicates that water productivity at 10 -DAD are more than 8-DAD due to less water requirement but in respect of yield 8 DAD treatment out yielded 10 DAD due to efficient use of water.

\section{ACKNOWLEDGEMENT}

The authors wish to acknowledge Ministry of Science and Technology (MOST), Government of the People's Republic of Bangladesh for funding this research project and technical support.

Open Access: This is open access article distributed under the terms of the Creative Commons Attribution License, which permits unrestricted use, distribution, and reproduction in any medium, provided the original author(s) and the source are credited.

\section{REFERENCES}

Akita, S. (1989). Improving yield potential in tropical rice. In: Progress in Irrigated Rice Research. Manila, the Philippines, International Rice Research Institute. pp. 41-73.

Alam, M.M., Ali, M.H., Hasanuzzaman, M., Nahar, K. and Islam, M.R. (2009). Dry matter partitioning in hybrid and inbred rice varieties undervariable doses of phosphorus. International Journal of Sustainable Agriculture, 1: 10-19.

Amano, T., Zhu, Q., Wang, Y., Inoue, N. and Tanaka, H. (1993). Case studies on high yields of paddy rice in Jiangsu Province China: I. Characteristicsof grain production. Japanese Journal of Crop Science, 62: 267-274.

Arora, V.K. (2006). Application of a rice growth and water balance model in an irrigated semi-arid subtropical environment. Agricultural Water Management, 83: 51-57.

Barker, R., Dawe, D., Tuong, T.P., Bhuiyan, S.I. and Guerra, L.C. (1998). The outlook for water resources in the year 2020: challenges for research on water management in rice production. In: Assessment and Orientation towards the 21st Century. Proceedings of the 19th Session of the International Rice Commission, 7-9 September 1998, Cairo, Egypt. Food and Agriculture Organization, pp: 96-109.

Belder, P., Bouman, B.A.M., Cabangon, R., Guoanm, L., Quilang, E.J.P., Li, Y., Spiertz, J.H.J. and Tuong, T.P. (2004).Effect of water saving irrigation on rice yield and water use in typical lowland conditions in Asia. Agricultural Water Management, 65:193-210.

Belder, P., Bouman, B.A.M. and Spiertz, J.H.J. (2007). Exploring options for water savingsin lowland rice using a modelling approach. Agricultural Systems, 92:91-114.

Bouman, B.A.M. (2007). A conceptual framework for the improvement of crop water productivity at different spatial scales. Agricultural Systems, 93:43-60.

Bouman, B.A.M., Lampayan, R.M. and Tuong, T.P. (2007).Water management in irrigated rice: coping with water scarcity. International Rice Research Institute, Los Banos, Philippines.

Bouman, B.A.M., Peng, S., Castaneda, A.R. and Visperas, R.M. (2005). Yield and water use of irrigated tropical aerobic rice systems.Agricultural Water Management, 74: 87-105.

Bouman, B.A.M. and Tuong, T.P. (2001). Field water management to savewater and increase its productivity in irrigated lowland rice. Agricultural Water Management, 49:11-30.

Fageria, N.K. (2007). Yield physiology of rice. Journal of Plant Nutrition, 30: 843-879.

Gomez, K.A. and Gomez, A.A. (1984). Statistical procedure for agricultural research. Second Edn., International Rice Research 
Institute, Los Banos, Manila, The Phillipines pp. 204-207.

Hunt, R. (1978). Plant Growth Analysis. Studies in Biology, No. 96. Edward Arnold (Publishes) Limited, 41. Bedford Square, London.

Islam, M.J. and Mondal, M.K. (1992). Water management strategy for increasing monsoon rice production in Bangladesh. Agricultural Water Management, 22:335-343.

Jahan, S., Sarkar, M.A.R. and Paul, S.K. (2017). Variations of growth parameters in transplanted Aman rice (cv. BRRI dhan39) in response to plant spacing and fertilizer management. Archives of Agriculture and Environmental Science, 2(1): 1-5.

Jana, K., Mallick, G.K., Das, S.K., Biswas, B., Kundu, M.K., Koireng, R.J. and Puste, A.M. (2017). Evaluation of potential rice (Oryza sativa L.) genotypes with different levels of $\mathrm{N}$ under rainfed shallow lowland situation. Archives of Agriculture and Environmental Science, 2(3): 202-205.

Kato, Y., Okami, M. and Katsura, K. (2009). Yield potential and water use efficiency of aerobic rice (Oryza sativa L.) in Japan. Field Crops Research, 113: 328-334.

Katsura, K., Maeda, S., Horie, T. and Shiraiwa, T. (2007). Analysis of yield attributes and crop physiological traits of Liangyoupeijiu, a hybrid rice recently bred in China. Field Crops Research, 1033:170-177.

Li, C.S., Ye, S.H., Chen, Y.Z., Ruan, G.H., Huang, F.D. and Zhang, X.M. (2005).The study on yield component factors of high yielding Japonica rice varieties. Acta Agriculture Zhejiangensis, 174:177-181.

Michael, A.M.. (1978). Irrigation Theory and Practice. Vika Publishing House, New Delhi.

Naher, U.A., Saleque, M.A., Panhwar, Q.A., Radziah, O. and Jusop, S. (2011). Techniques of efficient fertilizer management for wetland rice - a review. Australian Journal of Crop Science, 5: 1661-1669.

Peng, S., Cassman, K.G., Virmani, S.S., Sheehy, J. and Khush, G.S. (1999).Yield potential trends of tropical rice since the release of IR8 and the challenge of increasing rice yield potential. Crop Science, 39: 1552-1559.

Radford, P.J. (1967).Growth analysis formulae-their use and abuse. Crop Science, 7: 171-175.

Rahman, M.M. (2016). Weed management strategy for dry direct seeded rice. Advances in Plants and Agriculture Research, 3: 00114.

Sarkar, M.A.R., Hossain, M.A. and Paul, S.K. (2017). Impact of row arrangements, age of tiller seedlings and number of tiller seedlings hill-1 on the growth performance of transplanted Aman rice (cv. BR23). Archives of Agriculture and Environmental Science, 2(3): 152-161.

Sato, S. and Uphoff, N. (2007). A review of on-farm evaluation of system of rice intensification (SRI) methods in eastern Indonesia: $\mathrm{CAB}$ Reviews. Commonwealth Agricultural Bureau International, Wallingford, pp. 67-87.

Sharma, A.P. and Singh, S.P. (1994). Genotypic variation in photosynthesis and yield components in rice. Indian Journal of Plant Physiology, 37:188-189.

Singh, P., Agrawal, M. and Agrawal, S.B. (2009). Evaluation of physiological, growth and yield responses of a tropical oil crop (Brassica campestris L. var. Kranti) under ambient ozone pollution at varying NPK levels. Environmental Pollution, 157: 871-880.

Singh, S., Ladha, J.K., Gupta, R.K., Bhusan, L. and Rao, A.N. (2008). Weed management in aerobic rice systems under varying establishment methods. Crop Protection, 27: 660-671.

Smart, R.E. and Bingham, G.E. (1974). Rapid estimates of relative water content. Plant Physiology, 53: 258-260.

Tabbal, D.F., Bouman, B.A.M., Bhuiyan, S.I., Sibayan, E.B. and Sattar, M.A. (2002). On-farm strategies for reducing water input in irrigated rice: case studies in the Philippines. Agricultural Water Management, 56: 93-112.

Tuong, T.P. and Bouman, B.A.M. (2002). Rice production in water scarce environments, in Water Productivity in Agriculture: Limits and Opportunities for Improvement, J.W. Kijne, R. Barker, and D. Molden, Eds., vol. 1 of The Comprehensive Assessment of Water Management in Agriculture Series, pp. 13-42, CABI, Wallingford, UK, 2002.

Tuong, T.P., Bouman, B.A.M. and Mortimer, M. (2005). More rice, less water integrated approaches for increasing water productivity in irrigated rice-based systems in Asia. Plant Production Science, 8: 231-241.

Yamakawa, H., Hirose, T., Kuroda, M. and Yamaguchi, T. (2007). Comprehensive Expression Profiling of Rice Grain FillingRelated Genes under High Temperature Using DNA Microarray. Plant Physiology, 144: 258-277.

Yang, C., Yang, L., Yang, Y. and Ouyang, Z. (2004). Rice root growth and nutrient uptake as influenced by organic manure in continuously and alternately flooded paddy soils. Agricultural Water Management, 70: 67-81.doi.org/10.1016/ j.agwat.2004.05.003.

Yang, W., Peng, S., Dionisio-Sese, M.L., Laza, R.C. and Visperas, R.M.(2008). Grain filling duration, a crucial determinant of genotypic variation of grain yield in field-grown tropical irrigated rice. Field Crops Research, 105: 221-227.

Yoshida, H., Horie, T. and Shiraiwa, T. (2006). A model explaininggenotypic and environmental variation of rice spikeletnumber per unit area measured by cross-locational experiments in Asia. Field Crops Research, 97: 337-343.

Zadoks, J.C., Chang, T.T. and Konzat, C.F. (1974). A decimal code for the growth stages of cereals. Weed Research, 14: 415-421.

Zain, N.A.M., Ismail, M.R., Puteh, A., Mahmood, M. and Islam, M.R. (2014). Impact of cyclic water stress on growth, physiological responses and yield of rice (Oryza sativa L.) grown in tropical environment. Ciencia Rural [online], 44: 2136-2141.

Zhang, H., Xue, Y., Wang, Z., Yang, J. and Zhang, J. (2009). An alternate wetting and moderate soil drying regime improves root and shoot growth in rice. Crop Science, 49: 2246-2260. 